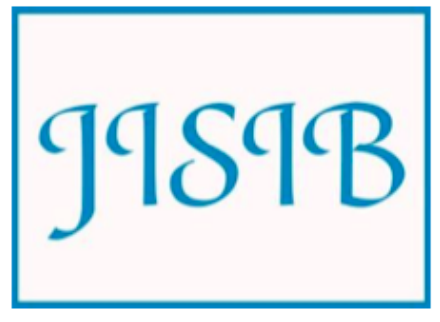

Available for free online at https://ojs.hh.se/

Journal of Intelligence Studies in Business Vol 5, No 2 (2015) 48-58

\title{
Leveraging organizational knowledge vision through Strategic Intelligence profiling - the case of the Romanian software industry
}

\author{
Gianita Bleoju ${ }^{1}$ and Alexandru Capatina ${ }^{2}$ \\ ${ }^{1}$ Dunarea de Jos University of Galati, Romania, Postdoctoral researcher - Al. I. Cuza \\ University of Iasi, Romania \\ ${ }^{2}$ Dunarea de Jos University of Galati, Romania \\ gianita.bleoju@ugal.ro \\ alexandru.capatana@ugal.ro
}

Received June 7, accepted August 102015

\begin{abstract}
This paper presents the empirical testing of a Strategic Intelligence profiling tool customized for software development companies that we have previously designed, through an abductive methodology. We conducted a quantitative survey to identify the associations between the strategic profiles embedded into the profiling tool (Intelligence Provider, Vigilant Learner, Opportunity Captor and Opportunity Defender) and four variables with high impact on organizational knowledge: strategic scope, organizational agility, organizational cultural change process and the approach of competitors. We found that the relevance of our Strategic Intelligence tool's variables is a consistent base for testing the robustness of the model in software industry, in order to validate the profiling instrument. We consider that the originality of the Strategic Intelligence profiling tool, tailored to software industry requirements, resides mainly in the foresight capability of the firm, which is highly dependent on less acknowledgeable factors such as: anticipative versus non-anticipative signal processing; the profile specific equilibrium of recognitional versus analytical strategic decision and rising the actionability of tacit managerial knowledge through collective intelligence reliability.
\end{abstract}

KEYWORDS: Strategic Intelligence, maturity model, software industry, Vigilant Learner, Opportunity Captor, Opportunity Defender, Intelligence Provider 


\section{Introduction}

Our research is focused on the empirical testing, by means of appropriate statistical methods, of a conceptual Strategic Intelligence matrix reflecting four strategic profiles related to software development companies (Vigilant Learner, Opportunity Captor, Opportunity Defender and Intelligence Provider).

We conducted a quantitative survey in view to identify the correlations between the strategic profiles embedded into the above mentioned profiles and four variables with high impact on organizational knowledge modeling: strategic scope, organizational agility, organizational cultural change process and the approach of competitors.

The statistical methods that we used in order to analyze the hypotheses are cross-tabulations and chisquare tests, on a sample of 106 companies from the Romanian software industry landscape.

The paper is organised as follows: literature review, research methodology, findings and results, valorizing similarities of organizational knowledge vision approaches and we conclude with current and future industry challenges addressed by the profiling tool.

\section{Strategic Intelligence in software industry: a literature review}

Strategic intelligence should provide a company with the information about its business environment; thus, it will be capable to predict changes, design appropriate strategies that will create business value for customers and facilitate the future development for the company in new markets within or across industries (Xu, 2007).

McDowell (2008) considers Strategic Intelligence as being the ability of management to shape itself to fit the particular informational needs of the organization, providing the type of analysis that relates directly to achieving the strategic goals.

According to Pellisier and Kruger (2011), Strategic Intelligence is the result of the synergy between business intelligence, competitive intelligence and knowledge management, allowing organizations to embed all their information into an easily manageable system in order to meet the intelligence requirements of management's strategic planning.

In the software industry framework, with such intense competition, a company needs a method of analyzing its environment that is more fundamental than the typical methods of scanning and trend analysis. Software companies confronted with major uncertainties and life-threatening competition should implement the scenario analysis method. Moreover, identifying the interrelationships of the relevant trends that will significantly affect the software industry represents a challenging Strategic Intelligence task that can be achieved through specialized tools such as influence diagrams and causal maps (Schoemaker, 2012).
Software development projects require knowledge embodied in project managers and software developers, as well as knowledge embedded in technological systems. According to Leonard-Barton (1992), "the closer the alignment of project and core knowledge set, the stronger the enabling influence". Ethiraj et al. (2005) suggested that strategic capabilities of software development companies are context-specific and evolve over time through the joint effects of deliberate, persistent firm-specific investments and learning-by-doing approaches.

Software companies can prepare for technological innovation by sharing intellectual assets through knowledge intensive alliances, recognizing their great use in setting the leading edge of technology and shaping the marketplace (Duysters et al., 1999). In this context, the Strategic Intelligence radars allow them to capture the collaborative opportunities.

The emergence of new technologies makes software development more efficient, but at the same time, it is difficult for developers to become proficient with a new technology and managers to understand its impact (Lindvall and Rus, 2002); in our opinion, the best way to face this challenge is to capture knowledge from the software industry, using the appropriate Strategic Intelligence tools.

Embeddedness and knowledge transfer are key determinants of software industry clusters that lead to global competitiveness (Dayasindhu, 2002); by taking into consideration these findings, we can state that, dealing with Strategic Intelligence programs, software development organizations are able to design processes for knowledge transfer and build strategic management capabilities.

Ajila and Sun (2004) investigated two approaches to delivering knowledge to software development projects: "push" and "pull". First approach is based on tools which allow identifying and providing knowledge to potential users, while the second approach considers that users themselves have to use repositories and other tools to identify relevant knowledge. In both cases, Strategic Intelligence capabilities are highly required, in order to facilitate the knowledge transfer.

The agile methodologies embedded in software development practices can be considered the most significant outcomes of Strategic Intelligence processes. We have in view four methodologies (Meso and Jain, 2006): incremental (small software releases with rapid development cycles), cooperative (a close customer and developer interaction), straightforward (considering the possible adjustments during the development process.) and adaptive (an ability to make and react to unpredictable changes). Moreover, they address flexibility at the project/product level, but higher level portfolio and product management are beyond the scope, improving performance and reliability through situationally specific strategies, processes and practices (Kettunen, 2009).

One of the main findings of a research coordinated by Aurum (2008) in the software 
industry reveals that software developers believe in the usefulness of knowledge sharing; the role played by personal networks in capturing and spreading tacit and implicit knowledge was considered as a pillar to foster a culture that encourages IT professionals to share their knowledge with others from the software industry; we appreciate that this process is the key enabler of the collaborative innovation networks' development. The main findings of a research conducted by Von Krogh et al. (2001) reveals the fact that by sharing existing knowledge on competitors and regulatory environments, the software organizations become increasingly aware of competitors' moves and possible policy changes that could affect the performance of the company. In their goal to effectively manage speed and change in software development process, the strategic outcomes of agile software companies cannot be predicted in the normal sense of cause-and-effect relationships, but they can be generated by means of patterns, generated through Strategic Intelligence systems, that have previously produced similar results (Highsmith, 2013).

\section{Research methodology}

On the basis of a previous research (Bleoju and Capatina, 2014), based on abductive methodology, reflecting four strategic profiles related to software development companies (Vigilant Learner, Opportunity Captor, Opportunity Defender and Intelligence Provider) according to their positioning into an innovative Strategic Intelligence Maturity Model - SIMM (Figure 1), we developed a conceptual model (Figure 2) and four hypotheses to be tested by means of appropriate statistical methods. We chose abductive methodology in the process of designing Strategic Intelligence Maturity Model, due to its power to capture and take advantage not only of the systemic character of the empirical evidence from business world, but also of the systemic character of our theoretical model. Thus, the dimensions of analysis and the names of SIMM profiles were previously discussed and validated by experts from software development companies, before their integration into the current research conceptual framework.

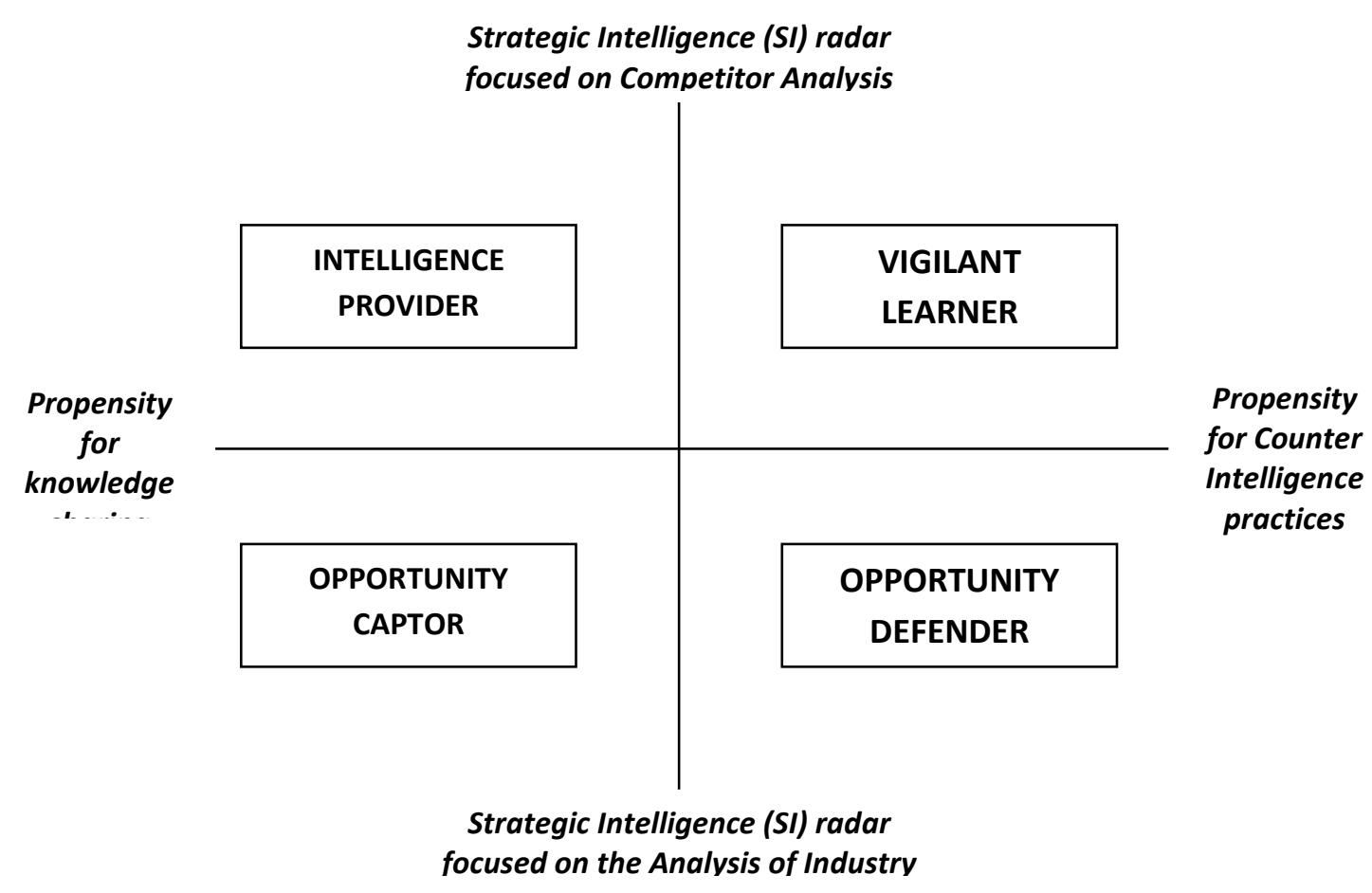

Figure 1 - Strategic Intelligence Maturity Model - SIMM

(Source: primary research)

Having in mind the strategic profiles highlighted in SIMM, we state four hypotheses in order to determine the existence of associations with four relevant variables (strategic scope, organizational agility, organizational cultural change process and approach of competitors' threats).

* Hypothesis 1: The strategic profiles of the Romanian software companies included into research sample are related to their strategic scope.
* Hypothesis 2: The strategic profiles of the Romanian software companies included into research sample are related to their organizational agility.

* Hypothesis 3: The strategic profiles of the Romanian software companies included into research sample are related to their organizational cultural change process.

* Hypothesis 4: The strategic profiles of the Romanian software companies included into 
research sample are related to their approach of competitors' threats.

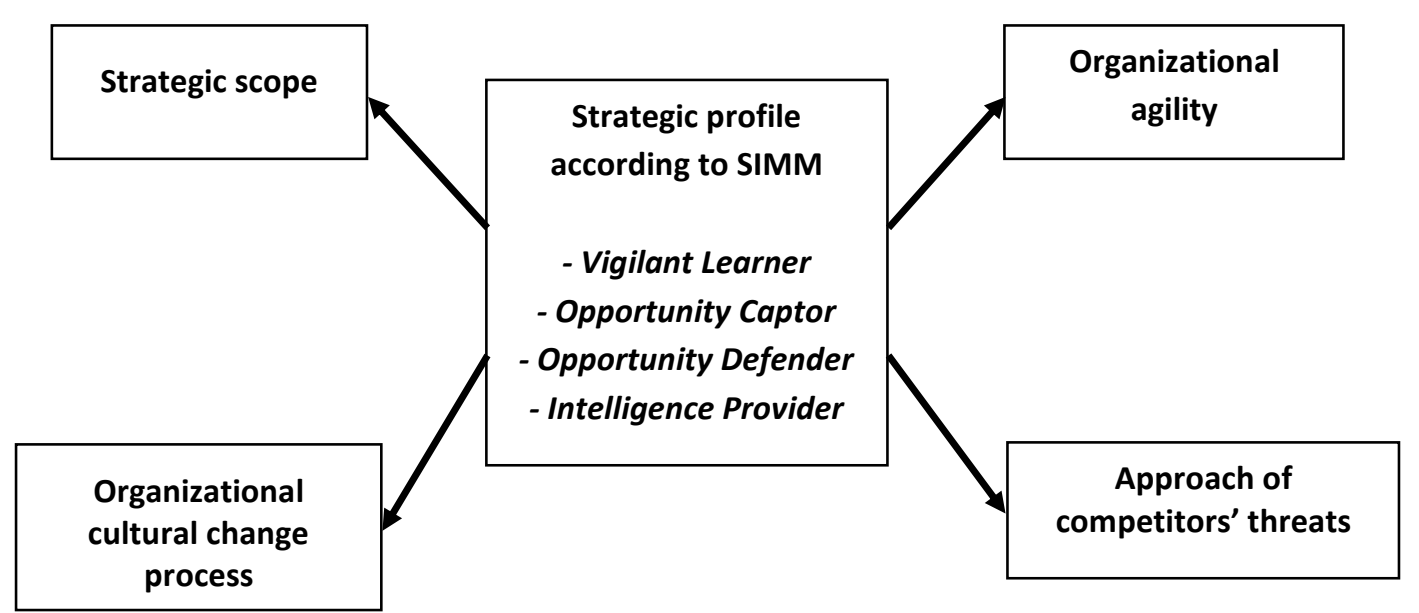

Figure 2: Conceptual model of the research

Each hypothesis aims at identifying the associations between the Strategic profile of the software development companies and relevant features related to each variable, according to the Table no. 1

Table 1 - Assumptions of relevant variables associations according to SIMM framework

\begin{tabular}{|l|l|l|l|l|l|}
\hline No & \multicolumn{1}{|c|}{ Variable } & \multicolumn{1}{|c|}{$\begin{array}{c}\text { Intelligence } \\
\text { Provider }\end{array}$} & \multicolumn{1}{|c|}{$\begin{array}{c}\text { Vigilant } \\
\text { Learner }\end{array}$} & $\begin{array}{c}\text { Opportunity } \\
\text { Captor }\end{array}$ & \multicolumn{1}{c|}{$\begin{array}{c}\text { Opportunity } \\
\text { Defender }\end{array}$} \\
\hline 1. & Strategic scope & $\begin{array}{l}\text { Differentiation } \\
\text { through knowledge } \\
\text { sharing }\end{array}$ & $\begin{array}{l}\text { Acquisition of } \\
\text { new knowledge }\end{array}$ & $\begin{array}{l}\text { Competences } \\
\text { portability }\end{array}$ & $\begin{array}{l}\text { Effective reaction } \\
\text { to strategic } \\
\text { movements of the } \\
\text { competitors }\end{array}$ \\
\hline 2. & $\begin{array}{l}\text { Organisational } \\
\text { agility }\end{array}$ & Strategic agility & Process agility & Portfolio agility & Operational agility \\
\hline 3. & $\begin{array}{l}\text { Organisational } \\
\text { cultural change } \\
\text { process }\end{array}$ & $\begin{array}{l}\text { Weak signals of } \\
\text { cultural dissonance } \\
\text { Approach of }\end{array}$ & $\begin{array}{l}\text { Culture } \\
\text { favourable to } \\
\text { changes }\end{array}$ & $\begin{array}{l}\text { Capacity to value } \\
\text { the cultural } \\
\text { differences }\end{array}$ & $\begin{array}{l}\text { Capability to } \\
\text { monitor the cultural } \\
\text { changes }\end{array}$ \\
\hline 4. & $\begin{array}{l}\text { Permanent care for } \\
\text { upgrades and } \\
\text { innovations }\end{array}$ & $\begin{array}{l}\text { Focus on } \\
\text { meeting the } \\
\text { clients' needs } \\
\text { instead of } \\
\text { attacking rivals }\end{array}$ & $\begin{array}{l}\text { Competitive } \\
\text { advantage on } \\
\text { harvesting over } \\
\text { competences' } \\
\text { portability }\end{array}$ & $\begin{array}{l}\text { High capacity to } \\
\text { detect competitors' } \\
\text { threats }\end{array}$ \\
\hline
\end{tabular}

Due to the fact that we embedded nominal variables in the conceptual research model, we analyzed the data by means of cross-tabs and tested the hypothesis with chi-square method, which is used to investigate whether distributions of our variables differ from one to another. The chi-square compares the observed count in each table cell to the count which would be expected under the assumption of association between the variables included in cross-tabs. A low p-value $(<0.05)$ indicates greater statistical significance, outlining a greater confidence and confirming that the observed deviation from the null hypothesis is significant.

\section{Findings and results}

In this section, we will outline the results of the four hypotheses tested through chi-square method, as previously mentioned.

Hypothesis 1: The strategic profiles of the Romanian software companies included into research sample are related to their strategic scope. 
Table 2 - Cross-tabulation between strategic profile and strategic scope

\begin{tabular}{|c|c|c|c|c|c|c|c|}
\hline & & & \multicolumn{4}{|c|}{ Strategic scope } & \multirow[b]{2}{*}{ Total } \\
\hline & & & $\begin{array}{l}\text { Differentiation } \\
\text { through } \\
\text { knowledge } \\
\text { sharing }\end{array}$ & $\begin{array}{c}\text { Acquisition of } \\
\text { new knowledge }\end{array}$ & $\begin{array}{c}\text { Competences } \\
\text { portability }\end{array}$ & $\begin{array}{c}\text { Effective reaction } \\
\text { to strategic } \\
\text { movements of } \\
\text { the competitors }\end{array}$ & \\
\hline \multirow[t]{12}{*}{ Strategic profile } & \multirow[t]{3}{*}{ Intelligence Provider } & Count & 9 & 1 & 2 & 2 & 14 \\
\hline & & Expected Count & 4.1 & 4.2 & 3.0 & 2.6 & 14.0 \\
\hline & & $\%$ within Strategic scope & $29.0 \%$ & $3.1 \%$ & $8.7 \%$ & $10.0 \%$ & $13.2 \%$ \\
\hline & \multirow[t]{3}{*}{ Opportunity Captor } & Count & 11 & 21 & 7 & 2 & 41 \\
\hline & & Expected Count & 12.0 & 12.4 & 8.9 & 7.7 & 41.0 \\
\hline & & $\%$ within Strategic scope & $35.5 \%$ & $65.6 \%$ & $30.4 \%$ & $10.0 \%$ & $38.7 \%$ \\
\hline & \multirow[t]{3}{*}{ Vigilant Learner } & Count & 5 & 5 & 8 & 4 & 22 \\
\hline & & Expected Count & 6.4 & 6.6 & 4.8 & 4.2 & 22.0 \\
\hline & & \% within Strategic scope & $16.1 \%$ & $15.6 \%$ & $34.8 \%$ & $20.0 \%$ & $20.8 \%$ \\
\hline & \multirow[t]{3}{*}{ Opportunity Defender } & Count & 6 & 5 & 6 & 12 & 29 \\
\hline & & Expected Count & 8.5 & 8.8 & 6.3 & 5.5 & 29.0 \\
\hline & & $\%$ within Strategic scope & $19.4 \%$ & $15.6 \%$ & $26.1 \%$ & $60.0 \%$ & $27.4 \%$ \\
\hline \multirow{3}{*}{\multicolumn{2}{|c|}{ Total }} & Count & 31 & 32 & 23 & 20 & 106 \\
\hline & & Expected Count & 31.0 & 32.0 & 23.0 & 20.0 & 106.0 \\
\hline & & $\%$ within Strategic scope & $100.0 \%$ & $100.0 \%$ & $100.0 \%$ & $100.0 \%$ & $100.0 \%$ \\
\hline
\end{tabular}

Table 3-Chi-Square Tests related to first hypothesis

\begin{tabular}{|l|r|r|r|}
\hline & Value & df & $\begin{array}{c}\text { Asymp. Sig. } \\
\text { (2-sided) }\end{array}$ \\
\hline Pearson Chi-Square & $32.647^{\mathrm{a}}$ & 9 & 0.000154 \\
Likelihood Ratio & 31.176 & 9 & 0.000276 \\
Linear-by-Linear Association & 13.480 & & 1 \\
N of Valid Cases & 106 & & 0.000241 \\
\hline
\end{tabular}

As p-value determined in this case $(0.000154)$ is smaller than the level of significance (0.05) and Pearson Chi-Square value (32.674) is higher than its standardized value reflected by Chi Square Distribution Table for 9 degrees of freedom $(16,919)$, we can conclude that there is an association between strategic profiles of the Romanian software companies included into research sample and their strategic scope.

The in-depth analysis of the research results outlines Opportunity Captors and Opportunity Defenders' behavior, as regard new knowledge aquisition and effective reaction against competition, while the other two profiles Intelligence Provider and Vigilant Learner are validating their identity upon featuring Sharing knowledge and Competence portability respectively.

The strategic scope features: knowledge sharing differentiation; acquisition of new knowledge; competence portability and effective reaction to strategic movements of competitors are best matching the SI profiling role upon leveraging organizational knowledge vision.

Our SIMM claims to overcome the rigidity of a traditional maturity framework, being designed as auto adjustable actionable learning solution, through recalibrating the classical assessment toward a portfolio of exploring anticipative maturity profilespecific trajectories.

The observed strategic scope could become a relevant precursor for setting up a strategic trajectory portfolio based on renewal organizational knowledge vision statement, consistent with an emergent competitive identity.

Hypothesis 2: The strategic profiles of the Romanian software companies included into research sample are related to their organizational agility. 
Table 4 - Cross-tabulation between strategic profile and organizational agility

\begin{tabular}{|c|c|c|c|c|c|c|c|}
\hline & & & \multicolumn{4}{|c|}{ Organizational agility } & \multirow[b]{2}{*}{ Total } \\
\hline & & & Strategic agility & Process agility & Portfolio agility & Operational agility & \\
\hline \multirow{12}{*}{$\begin{array}{l}\text { Strategic } \\
\text { profile }\end{array}$} & \multirow[t]{3}{*}{ Intelligence Provider } & Count & 6 & 2 & 3 & 3 & 14 \\
\hline & & Expected Count & 3.6 & 3.7 & 3.4 & 3.3 & 14.0 \\
\hline & & $\%$ within Organizational agility & $22.2 \%$ & $7.1 \%$ & $11.5 \%$ & $12.0 \%$ & $13.2 \%$ \\
\hline & \multirow[t]{3}{*}{ Opportunity Captor } & Count & 8 & 20 & 7 & 6 & 41 \\
\hline & & Expected Count & 10.4 & 10.8 & 10.1 & 9.7 & 41.0 \\
\hline & & $\%$ within Organizational agility & $29.6 \%$ & $71.4 \%$ & $26.9 \%$ & $24.0 \%$ & $38.7 \%$ \\
\hline & \multirow[t]{3}{*}{ Vigilant Learner } & Count & 8 & 2 & 10 & 2 & 22 \\
\hline & & Expected Count & 5.6 & 5.8 & 5.4 & 5.2 & 22.0 \\
\hline & & $\%$ within Organizational agility & $29.6 \%$ & $7.1 \%$ & $38.5 \%$ & $8.0 \%$ & $20.8 \%$ \\
\hline & \multirow[t]{3}{*}{ Opportunity Defender } & Count & 5 & 4 & 6 & 14 & 29 \\
\hline & & Expected Count & 7.4 & 7.7 & 7.1 & 6.8 & 29.0 \\
\hline & & $\%$ within Organizational agility & $18.5 \%$ & $14.3 \%$ & $23.1 \%$ & $56.0 \%$ & $27.4 \%$ \\
\hline \multirow{3}{*}{\multicolumn{2}{|c|}{ Total }} & Count & 27 & 28 & 26 & 25 & 106 \\
\hline & & Expected Count & 27.0 & 28.0 & 26.0 & 25.0 & 106.0 \\
\hline & & $\%$ within Organizational agility & $100.0 \%$ & $100.0 \%$ & $100.0 \%$ & $100.0 \%$ & $100.0 \%$ \\
\hline
\end{tabular}

Table 5 - Chi-Square Tests related to second hypothesis test

\begin{tabular}{|c|c|c|c|}
\hline & Value & df & $\begin{array}{l}\text { Asymp. Sig. } \\
\text { (2-sided) }\end{array}$ \\
\hline Pearson Chi-Square & $32.783^{\mathrm{a}}$ & 9 & 0.000146 \\
\hline Likelihood Ratio & 30.739 & 9 & 0.000328 \\
\hline $\begin{array}{l}\text { Linear-by-Linear } \\
\text { Association }\end{array}$ & 6.752 & 1 & .009 \\
\hline $\mathrm{N}$ of Valid Cases & 106 & & \\
\hline
\end{tabular}

a. 4 cells $(25.0 \%)$ have expected count less than 5 . The minimum expected count is 3.30 .

The second hypothesis tested outlines that strategic profiles of the Romanian software companies are related to their organizational agility and is validated by chi-square test, which indicates an association between the variables strategic profiles and organizational agility, as a result of a p-value equal to 0.000146 .

The organizational agility main characteristics, identifying and capture opportunities, prove to be sustained by Opportunity Captor process focusing, Vigilant Learner focalized on products and services, while Opportunity Defender' main feature is operational efficiency. We observe also the expected Intelligence provider identity based mainly on Strategic agility.

The organisational agility is the locus of understanding the rationale of the SIMM conceptual approach and highlights its leveraging role by structuring distinctively the organizational knowledge vision. Mapping the bundle of organizational capabilities, SIMM is also empowering the intelligent filtering through prioritized opportunities, both internal (OC and OD process and operational agility) and external (IP and VL strategic and portfolio agility).

Hypothesis 3: The strategic profiles of the Romanian software companies included into research sample are related to their organizational cultural change process. 
Table 6-Cross-tabulation between strategic profile and organizational cultural change

\begin{tabular}{|c|c|c|c|c|c|c|c|}
\hline & & & \multicolumn{4}{|c|}{ Organisational cultural change process } & \multirow[b]{2}{*}{ Total } \\
\hline & & & $\begin{array}{c}\text { Weak signals of } \\
\text { cultural } \\
\text { dissonance }\end{array}$ & $\begin{array}{c}\text { Culture } \\
\text { favourable to } \\
\text { changes }\end{array}$ & $\begin{array}{l}\text { Capacity to } \\
\text { value the } \\
\text { cultural } \\
\text { differences }\end{array}$ & $\begin{array}{l}\text { Capability to } \\
\text { monitor the } \\
\text { cultural } \\
\text { changes }\end{array}$ & \\
\hline \multirow{12}{*}{$\begin{array}{l}\text { Strategic } \\
\text { profile }\end{array}$} & \multirow[t]{3}{*}{ Intelligence Provider } & Count & 5 & 3 & 3 & 3 & 14 \\
\hline & & Expected Count & 2.8 & 3.4 & 3.7 & 4.1 & 14.0 \\
\hline & & $\begin{array}{l}\text { \% within Organisational } \\
\text { cultural change process }\end{array}$ & $23.8 \%$ & $11.5 \%$ & $10.7 \%$ & $9.7 \%$ & $13.2 \%$ \\
\hline & \multirow[t]{3}{*}{ Opportunity Captor } & Count & 7 & 16 & 7 & 11 & 41 \\
\hline & & Expected Count & 8.1 & 10.1 & 10.8 & 12.0 & 41.0 \\
\hline & & $\begin{array}{l}\text { \% within Organisational } \\
\text { cultural change process }\end{array}$ & $33.3 \%$ & $61.5 \%$ & $25.0 \%$ & $35.5 \%$ & $38.7 \%$ \\
\hline & \multirow[t]{3}{*}{ Vigilant Learner } & Count & 4 & 1 & 10 & 7 & 22 \\
\hline & & Expected Count & 4.4 & 5.4 & 5.8 & 6.4 & 22.0 \\
\hline & & $\begin{array}{l}\text { \% within Organisational } \\
\text { cultural change process }\end{array}$ & $19.0 \%$ & $3.8 \%$ & $35.7 \%$ & $22.6 \%$ & $20.8 \%$ \\
\hline & \multirow[t]{3}{*}{ Opportunity Defender } & Count & 5 & 6 & 8 & 10 & 29 \\
\hline & & Expected Count & 5.7 & 7.1 & 7.7 & 8.5 & 29.0 \\
\hline & & $\begin{array}{l}\% \text { within Organisational } \\
\text { cultural change process }\end{array}$ & $23.8 \%$ & $23.1 \%$ & $28.6 \%$ & $32.3 \%$ & $27.4 \%$ \\
\hline \multirow{3}{*}{\multicolumn{2}{|c|}{ Total }} & Count & 21 & 26 & 28 & 31 & 106 \\
\hline & & Expected Count & 21.0 & 26.0 & 28.0 & 31.0 & 106.0 \\
\hline & & $\begin{array}{l}\text { \% within Organisational } \\
\text { cultural change process }\end{array}$ & $100.0 \%$ & $100.0 \%$ & $100.0 \%$ & $100.0 \%$ & $100.0 \%$ \\
\hline
\end{tabular}

Table 7 - Chi-Square Tests related to third hypothesis test

\begin{tabular}{|c|c|c|c|}
\hline & Value & df & $\begin{array}{l}\text { Asymp. Sig. } \\
\text { (2-sided) }\end{array}$ \\
\hline Pearson Chi-Square & $14.608^{\mathrm{a}}$ & $\overline{9}$ & 0.102273 \\
\hline Likelihood Ratio & 15.266 & 9 & 0.083873 \\
\hline $\begin{array}{l}\text { Linear-by-Linear } \\
\text { Association }\end{array}$ & 2.679 & 1 & 0.101681 \\
\hline $\mathrm{N}$ of Valid Cases & 106 & & \\
\hline
\end{tabular}

a. 5 cells $(31.3 \%)$ have expected count less than 5 . The minimum expected count is 2.77 .

As regards to the third hypothesis test process, we observe a lack of association between the analyzed variables: strategic profile and organizational cultural change process, due to a p-value (0.102273) higher than the level of significance (0.05) and Pearson ChiSquare value (14.608) smaller than its standardized value reflected by Chi Square Distribution Table for 9 degrees of freedom $(16,919)$. We also remark some in depth profile communalities in terms of the tested issue that we consider relevant to underline. First and foremost a culture opened to change is mostly approached by Opportunity Captor followed by the capacity to monitor the organisational change, which is also prevalent for Opportunity Defender. Vigilant Learner confirms its capacity to capitalise upon cultural diversity, while the Intelligence Provider is slightly more prone to the propensity of organisational change.
We consider that the invalidated hypothesis could be explained to the context sensitivity of cultural change process, due to both dynamism of the industry and heterogeneity of corporate culture that inertial declare the openness to change, but less serve to consolidate competitive identity.

As a maturity model, the SI profiling is validating its early warning role by signaling a risk of strategic dissonance upon the features of organizational cultural change and claim a therapeutic approach, through more refined decision making support, as based on non-repeatable behavior, in the attempt to fully evolve from the fragile capacity to monitor cultural change to the most profitable capacity to recognize the value of cultural differences.

Hypothesis 4: The strategic profiles of the Romanian software companies included into research sample are related to their approach of competitors' threats. 
Table 8 - Cross-tabulation between strategic profile and the approach of competitors' threats

\begin{tabular}{|c|c|c|c|c|c|c|c|}
\hline & & & \multicolumn{4}{|c|}{ Approach of competitors' threats } & \multirow[b]{2}{*}{ Total } \\
\hline & & & $\begin{array}{c}\text { Permanent care } \\
\text { for upgrades } \\
\text { and innovations }\end{array}$ & $\begin{array}{c}\text { Focus on } \\
\text { meeting the } \\
\text { clients' needs } \\
\text { instead of } \\
\text { attacking rivals }\end{array}$ & $\begin{array}{c}\text { Competitive } \\
\text { advantage on } \\
\text { harvesting over } \\
\text { competences' } \\
\text { portability }\end{array}$ & $\begin{array}{c}\text { High capacity to } \\
\text { detect } \\
\text { competitors' } \\
\text { threats }\end{array}$ & \\
\hline \multirow[t]{12}{*}{ Strategic profile } & \multirow[t]{3}{*}{ Intelligence Provider } & Count & 7 & 1 & 5 & 1 & 14 \\
\hline & & Expected Count & 3.0 & 2.5 & 4.0 & 4.5 & 14.0 \\
\hline & & $\begin{array}{l}\text { \% within Approach of } \\
\text { competitors' threats }\end{array}$ & $30.4 \%$ & $5.3 \%$ & $16.7 \%$ & $2.9 \%$ & $13.2 \%$ \\
\hline & \multirow[t]{3}{*}{ Opportunity Captor } & Count & 8 & 10 & 11 & 12 & 41 \\
\hline & & Expected Count & 8.9 & 7.3 & 11.6 & 13.2 & 41.0 \\
\hline & & $\begin{array}{l}\text { \% within Approach of } \\
\text { competitors' threats }\end{array}$ & $34.8 \%$ & $52.6 \%$ & $36.7 \%$ & $35.3 \%$ & $38.7 \%$ \\
\hline & \multirow[t]{3}{*}{ Vigilant Learner } & Count & 4 & 3 & 8 & 7 & 22 \\
\hline & & Expected Count & 4.8 & 3.9 & 6.2 & 7.1 & 22.0 \\
\hline & & $\begin{array}{l}\text { \% within Approach of } \\
\text { competitors' threats }\end{array}$ & $17.4 \%$ & $15.8 \%$ & $26.7 \%$ & $20.6 \%$ & $20.8 \%$ \\
\hline & \multirow[t]{3}{*}{ Opportunity Defender } & Count & 4 & 5 & 6 & 14 & 29 \\
\hline & & Expected Count & 6.3 & 5.2 & 8.2 & 9.3 & 29.0 \\
\hline & & $\begin{array}{l}\text { \% within Approach of } \\
\text { competitors' threats }\end{array}$ & $17.4 \%$ & $26.3 \%$ & $20.0 \%$ & $41.2 \%$ & $27.4 \%$ \\
\hline \multirow{3}{*}{\multicolumn{2}{|c|}{ Total }} & Count & 23 & 19 & 30 & 34 & 106 \\
\hline & & Expected Count & 23.0 & 19.0 & 30.0 & 34.0 & 106.0 \\
\hline & & $\begin{array}{l}\% \text { within Approach of } \\
\text { competitors' threats }\end{array}$ & $100.0 \%$ & $100.0 \%$ & $100.0 \%$ & $100.0 \%$ & $100.0 \%$ \\
\hline
\end{tabular}

Table 9 - Chi-Square Tests related to fourth hypothesis test

\begin{tabular}{|c|c|c|c|}
\hline & Value & df & $\begin{array}{l}\text { Asymp. Sig. } \\
\text { (2-sided) }\end{array}$ \\
\hline Pearson Chi-Square & $14.906^{\mathrm{a}}$ & $\overline{9}$ & 0.09355 \\
\hline Likelihood Ratio & 14.774 & 9 & 0.09732 \\
\hline $\begin{array}{l}\text { Linear-by-Linear } \\
\text { Association }\end{array}$ & 6.824 & 1 & 0.00899 \\
\hline $\mathrm{N}$ of Valid Cases & 106 & & \\
\hline
\end{tabular}

a. 6 cells $(37.5 \%)$ have expected count less than 5 . The minimum expected count is 2.51 .

The lack of association in the case of the fourth hypothesis - corresponding to a p-value (0.09355) higher than the level of significance (0.05) and Pearson Chi-Square value (14.906) smaller than its standardized value reflected by Chi Square Distribution Table for 9 degrees of freedom $(16,919)$ - outlines the idea that Opportunity Defender and Opportunity Captor strong competitive identity and capacity to detect and react to competition atacks, while Intelligence Provider is consistent with its originary extraction position on competitor analysis and industry trends.

The strategic intelligence undertake of this competitive identity profiling is proving useful for upgrading the perspective market oriented versus vision oriented behaviour of the firm and replacing it with the deeper organisational knowledge vision leading role on approaching organisational behaviour.

Starting with the third invalidated hypothesis we can observe the importance to redefine the organizational knowledge vision framework through anchoring our Strategic Intelligence profiling instrument and expose its leveraging role. Organizational cultural change approach is further analyzed on a comparative basis with another empirically validated complementarity research perspective of the literature.

\section{Valorizing similarities of organizational knowledge vision approaches}

The methodological relevance of the complementarily approaches (Action Research and Abductive methodology) outlines a strong validation of both SI profiling and risk failure factors of Strategic scanning projects. Their theoretical and managerial relevance is addressed in terms of maximize market opportunities for the former and minimize industry dissonance for the later.

Strategic Scanning projects Failure factors identified (Lesca \& Caron-Fasan, 2008) and validated (Lesca et al. 2012) are consistent with the SIMM because of key objectives similarity of both Strategic Scanning projects and SI profiling leveraging competitive information-through specific 
patterns of recognitional versus analytical decision making systems. The performance differentiator Organizational Capitalizing on anticipative capacity will enact as leveraging organizational knowledge vision, because encompasses a cognitive process approach of organizational cultural change.

Some fresh reflection is worth to highlight; the need of increased foresight capabilities at the organization level is already perceived as decisive for the future positioning, what it is not yet obvious and as such, compulsory to be acquired, is the tailoring of the optimal balance of both analytical and recognitional decision systems.

The misbalancing position however is stimulating the keep choosing alert, which defines a qualified ready to adjust perspective of organizational knowledge vision. This qualified organizational status- quo explained by profile specific precursors of cultural dissonance is measuring the capacity to deal with competing interests and conflicting objectives.

What we define "Ready to adjust perspective" is a cultural based specific internal environment selection prone to address the Collective Intelligence awareness, emergence and sense making, accordingly.

The ready to adjust approach to organizational decision system is consistent with inductive behavior presumption of fully awareness therefore assumed consequences and the subjectivity of any choice.

Organizational ready to adjust perspective and the role of our Strategic Intelligence profiling instrument by experimenting a whole range of strategic trajectories, from market oriented to vision oriented behavior, allow us to discriminate on types and breadth of decisional support. In formulating the needed decisional guidance it is compelling to distinguish between the following roles:

a. Consultancy-based upon sector specific deep understanding and suitable solution to be implemented; it contains the know what of the sector and adjust the knowhow of the profile. We advance the high risk of portability incongruence for collective intelligence sense making, but good enough for awareness assessment and emergence, as it is based on similarity of the solution already implemented. The uniqueness of the solution remains doubtful.

b. Business mentoring, being problem solving focused is distinctively offering decision making support to firm specific equilibrium, in terms of the suitable recognitional - analytical framework. It assists top management to identify organizational anticipative capacity needs in terms of knowledge deficit and profile positioning through organizational' future competence identification. The learning focus is to insure the development of the foresight capability of the firm through establishing the anticipatory capacity dimensions of a specific competitive identity and the future relevant capability of the firm by setting up the ready to adjust perspective. The solution is more profile tailored; therefore it will insure sustainability to assess industry dissonance risk.

c. Procedural animators, being action oriented, their role is to channel the leadership reflection and profile/firm specific capitalization (collective sense making) through qualified expertise (externally-therefore objective) minimizing any cultural dissonance (competing interests / conflicting objectives) in order to insure internalization of knowledge as organizational competence. Very probable an organizational reconfiguration is compelling, in order to insure the rising of the actionability of tacit managerial knowledge through experimenting (learning by doing approach) and the reliability of empowering collective intelligence. The capitalization on collective intelligence sense making becomes performance differentiator, through monitoring at best both cultural and industry dissonance risks, being based on commonalties trained and learnt. The most valuable insight of this solution is the development of organizational collective intelligence role settings based upon own knowledge based interaction (revealing practices of collective creation of sense by exposing reflection mechanisms).

We consider this role more context sensitive and therefore it is discriminating better between firms' competitive identities. We denominate this solution as qualified organization status-quo, as tailored to serve at best the foresight capability.

\section{Conclusions and future industry challenges addressed by the SIMM}

The preliminary conclusions about the SIMM's robustness test on empirics in Romanian software market is consistent with current debate around balancing inductive with analytical approach for better identify and address the conflicts between the different dynamics of theoretical and managerial framework in order to accommodate the methodological mix.

We consider that the literature neglects the following useful insights and we advocate that they could be relevant.

One first issue to underline is that our model does not claim to anticipate patterns of organizational strategic behavior, but to channel the debate among researches toward the practitioner's emergency to dispose of conceptual toolkit. Exposing accountable tracking empirics will enable the managerial competence as qualified to discover, consolidate or adjust profile specific rules and routines, based upon commonalities trained and learned.

More specific to our case, the invalidation of the third and the fourth hypothesis highlights one significant difference between Opportunity Captor 
and Opportunity Defender profiles as regards organizational cultural change process and approach of competitor threats; these results are consistent with the propensity to repeatable versus non repeatable behavior approach, revealing practices of collective creation of sense, and their respective deriving organizational rules and routines. However, the two profiles (OC and OD) will adopt the ready to adjust perspective by consolidating their internal decisional structure with appropriate decisional support Business mentoring and Procedural animators, accordingly.

As regards expected capitalization over profile specific identity, we assert that ready to adjust perspective in the case of $\mathrm{OC}$ is to be the best positioned for industry future opportunity mapping, while OD will successfully address niche strategy design through the anticipation of the most favorable differentiation.

The Intelligence Provider behavior's best matching the organizational knowledge vision by capitalizing upon strategic resources, being prone to successfully approach the IT sector's most difficult future challenges, by means of its profile specific competence, best fitting to knowledge intensive demand. As the most illustrative example we can mention cyber security issues, better addressed by the multiplier effect of IP behavior as source of Strategic Intelligence solutions to be tested by the other tree profiles (VL, OC, OD) of our profiling tool embedded into SIMM.

The specific profile approaches to security issues and competitively (=separately) capitalizing on solutions, is becoming an unsustainable strategic behavior, not only due to the magnitude and spread of this threat, but because of envisaged software industry requirements, which will be successfully fulfil only by organizational foresight capability development.

The current key success factor-minimizing the customer concern (transaction cost approach) and detriment (targeting) outline the different profile's capacity to deal with it and is emphasizing a waste of knowledge resources. We advance that SIMM not only reveals the specific gap of market versus vision oriented behavior, but it is also able to support the managerial design of a portfolio of sustainable strategic trajectories to be deployed through profile specific collective intelligence instruments.

Using tacit managerial knowledge through experimenting and empowering collective intelligence reliability is the best solution for gradually improving the anticipative capacity of the firm insuring quasi-full coverage of future threats and taped opportunities.

We consider that SIMM and its experimental role is a powerful tool enabling the foresight capability of the firm through specific awareness focusing on knowledge resources modeling allocation. The above mentioned waste of knowledge resources can be avoided or adjusted by an disruptive approach based upon less acknowledgeable factors as: anticipative versus non-anticipative signal processing; the profile specific equilibrium of recognitional versus analytical strategic decision and rising the actionability of tacit managerial knowledge through collective intelligence reliability.

The broad outline of the foresight capability approach requires a preliminary analyze against critical influence factors: power, resources and independence on software industry, which reliability's the source of strategic capitalization upon successful anticipative capacity of the firm.

\section{Acknowledgements}

This work was supported by the European Social Fund through Sectorial Operational Programme Human Resources Development 2007 - 2013; project number POSDRU/159/1.5/S/142115, project title "Performance and Excellence in Postdoctoral Research in Romanian Economics Science Domain".

\section{References:}

Ajila, S. A., \& Sun, Z. (2004). Knowledge management: impact of knowledge delivery factors on software product development efficiency. In Information Reuse and Integration, 2004. IRI 2004. Proceedings of the 2004 IEEE International Conference on (pp. 320-325). IEEE.

Aurum, A., Daneshgar, F., \& Ward, J. (2008). Investigating Knowledge Management practices in software development organisations -An Australian experience. Information and Software Technology, 50(6), 511-533.

Capatina, A., Bleoju, G. (2014). The Specific Valorisation of Competitive Intelligence Profiling on the Software Industry, Proceedings of ECKM 2014, 189-197.

Dayasindhu, N. (2002). Embeddedness, knowledge transfer, industry clusters and global competitiveness: a case study of the Indian software industry. Technovation, 22(9), 551-560.

Duysters, G., Kok, G., \& Vaandrager, M. (1999). Crafting successful strategic technology partnerships. R\&D Management, 29(4), 343-351.

Ethiraj, S. K., Kale, P., Krishnan, M. S., \& Singh, J. V. (2005). Where do capabilities come from and how do they matter? A study in the software services industry. Strategic Management Journal, 26(1), 25-45.

Highsmith, J. (2013). Adaptive software development: a collaborative approach to managing complex systems. Addison-Wesley.

Kettunen, P. (2009). Adopting key lessons from agile manufacturing to agile software product development-A comparative study. Technovation, 29(6), 408-422.

Leonard-Barton, D. (1992). Core capabilities and core rigidities: A paradox in managing new product development. Strategic management journal, 13(S1), 111-125.

Lesca, H., \& Lesca, N. (2013). Weak signals for strategic intelligence: anticipation tool for managers. John Wiley \& Sons. 
Lesca, N., \& Caron-Fasan, M. L. (2008). Strategic scanning project failure and abandonment factors: lessons learned. European Journal of Information Systems, 17(4), 371-386.

Lesca, N., Caron-Fasan, M. L., \& Falcy, S. (2012). How managers interpret scanning information. Information \& Management, 49(2), 126-134.

Lindvall, M., \& Rus, I. (2002). Knowledge management in software engineering. IEEE software, 19(3), 0026-38.

McDowell, D. (2008). Strategic intelligence: a handbook for practitioners, managers, and users. Scarecrow Press.

Meso, P., \& Jain, R. (2006). Agile software development: adaptive systems principles and best practices. Information Systems Management, 23(3), 19-30.
Pellisier, R. \& Kruger, J-P., 2011, 'Understanding the use of strategic intelligence as a strategic management tool in the long-term insurance industry in South Africa', SA Journal of Information Management 13(1), doi:10.4102/sajim.v13i1.426

Schoemaker, P. J. (2012). How to link strategic vision to core capabilities. Sloan Management.

Von Krogh, G., Nonaka, I., \& Aben, M. (2001). Making the most of your company's knowledge: a strategic framework. Long range planning, 34(4), 421-439.

$\mathrm{Xu}, \quad$ M. (Ed.). (2007). Managing strategic intelligence: techniques and technologies. IGI Global. 